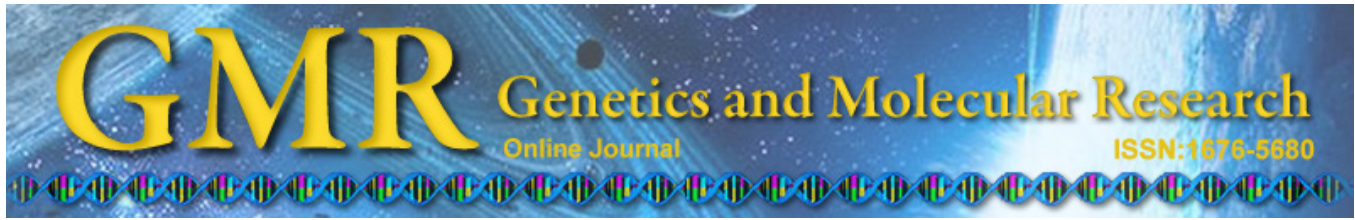

\title{
Comparison of small scale methods for the rapid and efficient extraction of mitochondrial DNA from wheat crop suitable for down-stream processes
}

\author{
M. Ejaz*, Z. Qidi*, Z. Gaisheng, W. Qunzhu, N. Na and Z. Huiyan \\ College of Agronomy, Northwest A\&F University, Yangling, Shaanxi, China \\ *These authors contributed equally to this study. \\ Corresponding author: Z. Gaisheng \\ E-mail: zhanggsh58@aliyun.com
}

Genet. Mol. Res. 13 (4): 10320-10331 (2014)

Received February 18, 2014

Accepted July 7, 2014

Published December 4, 2014

DOI http://dx.doi.org/10.4238/2014.December.4.27

\begin{abstract}
We evaluated and compared 2 mitochondrial DNA (mtDNA) extraction methods in terms of DNA quality and success of subsequent polymerase chain reaction (PCR) amplifications from etiolated leaves of wheat crop (Triticum aestivum). mtDNA extraction is difficult because the presence of metabolites interfere with DNA isolation procedures and downstream applications such as DNA restriction, amplification, and cloning. The method (with modification) involved inactivation of genomic DNA by DNase I enzyme, RNA by RNase enzyme, contaminant proteins by using proteinase $\mathrm{K}$, and precipitation of polysaccharides in the presence of a high salt concentration. The DNase I and RNA enzyme ratio was adjusted to $10: 8 \mu \mathrm{L}$. The purity of mtDNA was confirmed by PCR amplification of genomic, mitochondrial, and chloroplast (rbcL) gene. The mitochondrial COXIII gene of 400 bp was amplified; the $\beta$-actin and chloroplast genes were not amplified. $\mathrm{A}_{260}{ }^{\prime}$ $\mathrm{A}_{280}$ (1.89) and $\mathrm{A}_{260} / \mathrm{A}_{230}(2.07)$ ratios were calculated using a spectrophotometer. The isolated mtDNA was amenable to amplification and
\end{abstract}


restriction digestion. The technique is fast, reproducible, and suitable for PCR-based markers.

Key words: Extraction method; Mitochondrial DNA; Molecular markers; Triticum aestivum

\section{INTRODUCTION}

To provide food security to the rapidly growing world population is a major responsibility of agriculture in the 21 st century; this is necessary for achieving long-term economic and environmental sustainability of crop production through precision agriculture of food crops. Bread wheat was likely a central point in the beginning of agriculture and plays a major role among the few crop species being extensively grown as food sources (Harlan, 1981). Wheat is considered to be extremely important among cereal grains because its grain contains protein with unique chemical and physical properties. In addition to being a rich source of carbohydrates, wheat contains other valuable components such as protein, minerals $(\mathrm{P}, \mathrm{Mg}$, $\mathrm{Fe}, \mathrm{Cu}$, and $\mathrm{Zn}$ ), and vitamins (Adsule and Kadam, 1986).

Mitochondria are semiautonomous organelles that manufacture cellular ATP through oxidative phosphorylation in all eukaryotes. Lynch et al. (2006) reported that plant mitochondrial genomes, which are involved in the system of energy production by encoding the necessary proteins, play a significant role in plant development and reproduction and have a specific evolutionary pattern relative to the nuclear counterparts. Mitochondrial DNAs (mtDNAs) display distinctive features, including a slow evolutionary rate, rapid rearrangement, frequent insertion, complex multipartite structure, specific mode of gene expression, RNA editing, and use of the universal genetic code (Schuster and Brennicke, 1994). Gene shuffling and variations may result in different phenotypes, such as cytoplasmic male sterility (CMS). CMS is a common phenotype in higher plants and is closely associated with mutations in mtDNAs that cause pollen abortion. CMS systems have been widely used as a convenient method for producing F1 hybrid seeds in a variety of valuable crop species, including wheat, rice, maize, sugar beet, and cotton (Schnable and Wise, 1998).

Isolation of plant mitochondrial DNA for use in Southern blot analysis, polymerase chain reaction (PCR) amplifications, restriction fragment length polymorphisms, and arbitrary primed DNA amplifications [amplified fragment length polymorphism (AFLP), random amplification of polymorphic DNA, simple sequence repeat-PCR] is one of the most important and time-consuming steps. mtDNA extracts often contain large amounts of RNA, proteins, polysaccharides, tannins, and pigments, which may interfere with the extracted DNA and are difficult to separate (Puchooa, 2004). Most proteins are removed by denaturation and precipitation from the extract using chloroform and/or phenol. In contrast, RNAs are typically removed by treating the extract with heat-treated RNase. Polysaccharide-like contaminants are, however, more difficult to remove. They can inhibit the activity of certain DNA-modifying enzymes and may interfere with the quantification of DNA using spectrophotometric methods (Wilkie et al., 1993). A good extraction procedure for the isolation of mitochondria should yield adequate and intact mtDNA of reasonable purity. Karaca et al. (2005) reported that DNA extraction methods generally consist of the following steps: homogenization for the disruption of cells or tissue, denaturation of cell membranes and nucleoprotein complexes to break down the cells, and specific precipitation of DNA. 
The procedure should also be fast, simple, and inexpensive. To fulfill this criterion, a rapid, simple and reliable mtDNA isolation method is necessary. In this study, we compared 2 methods (mtDNA extraction) with alterations based on the classical principles of lyses and purification at Key Laboratory of Crop Heterosis of Shaanxi Province, Northwest Agricultural \& Forest University, Yangling, China. The first method has been described by Tang et al. (2005) and the second was defined by Li et al. (2007).

\section{MATERIAL AND METHODS}

\section{Plant material}

In this study, wheat (Triticum aestivum) line 90-110 was used. The seed was soaked in water for $6 \mathrm{~h}$; sprouted wheat seeds were grown in a dark growth chamber over a period of 7-10 days at $30^{\circ} \mathrm{C}$, which produced yellow etiolated seedlings. Sterile water was supplied and nutrients were supplied to meet the growth needs of the plants. The plants were carefully protected from light. All culture methods were conducted in the dark to prevent the plants from becoming green, enabling us to obtain high-quality mtDNA that was free from chloroplasts, genomic DNA, and other impurities.

\section{mtDNA isolation}

To obtain pure and high-quality mtDNA we compared 2 methods (mtDNA extraction) with adjustments based on classical principles of lyses and purification. The first method was described by Tang et al. (2005), while the second was defined by Li et al. (2007).

\section{Method I (Tang et al., 2005)}

Mitochondria were isolated at $4{ }^{\circ} \mathrm{C}$ using a method previously described by Tang et al. (2005), with some modifications. First, $20 \mathrm{~g}$ yellow etiolated shoots was washed and homogenized twice for $15 \mathrm{~s}$ in a cold Warring blender in $200 \mathrm{~mL}(10 \mathrm{~mL} / \mathrm{g})$ homogenization medium containing $50 \mathrm{mM}$ Tris-HCl, $\mathrm{pH} \mathrm{8,} 0.3 \mathrm{M}$ mannitol, $0.2 \mathrm{M}$ sucrose, $1 \mathrm{mM}$ EDTA-HCl, $\mathrm{pH} 8$, $0.6 \%$ polyvinylpyrrolidone (PVP), $0.1 \%$ bovine serum albumin (BSA), and $0.1 \% \beta$-mercaptoethanol. BSA, PVP, and $\beta$-mercaptoethanol added just before use. The homogenate was filtered through 5 layers of cheesecloth and centrifuged for $15 \mathrm{~min}$ at $3500 \mathrm{rpm}$. The resulting supernatant was centrifuged for $20 \mathrm{~min}$ at $10,000 \mathrm{rpm}$. The crude mitochondrial pellet was resuspended in suspension medium containing $50 \mathrm{mM}$ Tris- $\mathrm{HCl}, \mathrm{pH} 8,0.3 \mathrm{M}$ mannitol, $0.2 \mathrm{M}$ sucrose, $0.1 \%$ BSA, 0.6\% PVP (BSA and PVP added just before use), and centrifuged at 3500 $\mathrm{rpm}$ for $15 \mathrm{~min}$. The supernatant was then centrifuged at 10,000 rpm for $20 \mathrm{~min}$. The pelleted mitochondrial fraction was resuspended in $10 \mathrm{~mL}$ suspension medium $(0.3 \mathrm{M}$ sucrose, $50 \mathrm{mM}$ Tris- $\mathrm{HCl}, \mathrm{pH} 8)$, to which we added $100 \mu \mathrm{L} \mathrm{MgCl}_{2}(1 \mathrm{M})$ and $8 \mu \mathrm{L}$ DNase I enzyme (50 ng/ $\mu \mathrm{L}$ ) (Sigma, St. Louis, MO, USA), and the sample was incubated for 90 min on ice. Next, 750 $\mu \mathrm{L}$ EDTA-HCl, $\mathrm{pH} 8(0.5 \mathrm{M})$ solution was added and the sample was placed in an ice bath to stop the action of DNase I enzyme. The mitochondrial suspension was carefully placed on $20 \mathrm{~mL}$ washing medium containing $0.3 \mathrm{M}$ mannitol, $50 \mathrm{mM}$ Tris- $\mathrm{HCl}, \mathrm{pH} 8$, and $0.6 \mathrm{M}$ sucrose. The mitochondria were collected by centrifugation for $20 \mathrm{~min}$ at $10,000 \mathrm{rpm}$. Purified mitochondria were suspended in $4 \mathrm{~mL}$ lysis buffer containing $0.1 \mathrm{M} / \mathrm{L}$ Tris-HCl, $\mathrm{pH} 8,0.05 \mathrm{M}$ 
EDTA-HCl, $\mathrm{pH} 8,5 \%$ sodium dodecyl sulfate, $0.1 \mathrm{M} \mathrm{NaCl}, 0.1 \% \beta$-mercaptoethanol, and 100 $\mu \mathrm{g} / \mathrm{mL}$ potassium proteinase and lysed at $50^{\circ}$ and $37^{\circ} \mathrm{C}$ for $60 \mathrm{~min}$ at each temperature. The lysate was treated with phenol/chloroform/isoamyl alcohol (25:24:1) followed by ammonium acetate $(2 \mathrm{M})$ and extracted by centrifugation at $18,000 \mathrm{~g}$ for $5 \mathrm{~min}$; the centrifugation step was repeated twice. The supernatant was washed with chloroform/isoamyl alcohol (1:1) and centrifuged at $18,000 \mathrm{~g}$ for $5 \mathrm{~min}$. The supernatant was further digested by RNAse enzyme for $60 \mathrm{~min}$ at $37^{\circ} \mathrm{C}$. The product was mixed with $40 \mu \mathrm{L}$ sodium acetate, $\mathrm{pH} 5.2(3 \mathrm{M}), 800 \mu \mathrm{L}$ anhydrous ethanol, and incubated at $-70^{\circ} \mathrm{C}$ for $60 \mathrm{~min}$. mtDNA was pelleted by centrifugation at $18,000 \mathrm{~g}$ for $15 \mathrm{~min}$. mtDNA was washed twice with $70 \%$ ethanol and once with $96 \%$ ethanol, air-dried for $30 \mathrm{~min}$, liquefied in TE buffer (10 mM Tris-HCl, pH8 and $1 \mathrm{mM}$ EDTA-HCl, pH 8 ), and stored at $-20^{\circ} \mathrm{C}$ until further use.

\section{MethodII (Li et al., 2007)}

mtDNA was extracted following the protocol described by Li et al. (2007), with some modifications. We blended 20 g yellow etiolated shoots of wheat crop in an electric blender for $15 \mathrm{~s}$ (4 times) in high ionic-strength buffer [50 mM Tris-HCl, $\mathrm{pH} 8,1.3 \mathrm{M} \mathrm{NaCl}, 25 \mathrm{mM}$ EDTA-HCl, $\mathrm{pH} 8,0.2 \% \mathrm{BSA}, 0.05 \%$ cysteine, and $0.5 \% \beta$-mercaptoethanol (10 $\mathrm{mL} / \mathrm{g}$ tissue $)]$. BSA, cysteine, and $\beta$-mercaptoethanol were added just before use, and the blended mixture was filtered through 6 layers of Mira cloth and centrifuged 4 times (1000 $\mathrm{g}$ for $10 \mathrm{~min}$; $2000 \mathrm{~g}$ for $15 \mathrm{~min} ; 1000 \mathrm{~g}$ for $10 \mathrm{~min}$; $2000 \mathrm{~g}$ for $15 \mathrm{~min}$; and finally, 18,000 $\mathrm{g}$ for $20 \mathrm{~min}$ ) to pellet the mitochondria. The pelleted mitochondrial fraction was resuspended in $30 \mathrm{~mL}$ wash medium (50 $\mathrm{mM}$ Tris- $\mathrm{HCl}, \mathrm{pH} 8,1.3 \mathrm{M} \mathrm{NaCl}, 0.2 \% \mathrm{BSA}, 0.05 \%$ cysteine, and $0.5 \% \beta$-mercaptoethanol). $\mathrm{BSA}$, cysteine and $\beta$-mercaptoethanol added just before use and centrifuged at $18,000 \mathrm{~g}$ for $20 \mathrm{~min}$. To eliminate the nuclear DNA, mitochondrial pellets were resuspended in $780 \mu \mathrm{L}$ cold DNase I buffer and $10 \mu \mathrm{L} 1 \mathrm{U} / \mu \mathrm{L}$ DNase I enzyme (Fermentas, Vilnius, Lithuania) was added and the sample was incubated at $37^{\circ} \mathrm{C}$ for $60 \mathrm{~min}$. The reaction was stopped by adding $750 \mu \mathrm{L} 0.5 \mathrm{M}$ EDTA-HCl, $\mathrm{pH} 8$, and incubation at $37^{\circ} \mathrm{C}$ for $15 \mathrm{~min}$. Mitochondria were pelleted by centrifugation at $18,000 \mathrm{~g}$ for $20 \mathrm{~min}$ in buffer containing $50 \mathrm{mM}$ Tris- $\mathrm{HCl}, \mathrm{pH} \mathrm{8,} 400$ $\mathrm{mM}$ sucrose, and $0.2 \%$ BSA (BSA added just before use). Mitochondria were lysed in buffer containing 5\% sodium dodecyl sulfate, $25 \mathrm{mM}$ Tris-HCl, $\mathrm{pH} \mathrm{8,} 25 \mathrm{mM}$ EDTA-HCl, $\mathrm{pH}$ 8, and $0.1 \mathrm{M} \mathrm{NaCl}$ and incubated at $50^{\circ}$ and $37^{\circ} \mathrm{C}$ for $60 \mathrm{~min}$ at each temperature. The mitochondrium DNA was cleaned with phenol/chloroform/isoamyl alcohol (25:24:1), 2 M ammonium acetate and centrifuged at $18,000 \mathrm{~g}$ for $5 \mathrm{~min}$. RNA was removed from the samples by adding $20 \mu \mathrm{g} /$ $\mathrm{mL}$ DNase-free RNase enzyme (Fermentas) and incubation at $37^{\circ} \mathrm{C}$ for $1 \mathrm{~h}$. mtDNA was again washed with chloroform/isoamyl alcohol (24:1) and centrifuged at 18,000 $\mathrm{g}$ for $5 \mathrm{~min}$. The supernatant was precipitated at $-70^{\circ} \mathrm{C}$ for $1 \mathrm{~h}$ with $3 \mathrm{M}$ sodium acetate, $\mathrm{pH} 5.2$, and 2 volumes cold $100 \%$ ethanol. The mtDNA was pelleted by centrifugation at $18,000 \mathrm{~g}$ for $15 \mathrm{~min}$. The mtDNA was further washed twice with $70 \%$ ethanol and once with $100 \%$ ethanol and then airdried for $30 \mathrm{~min}$. The mtDNA was dissolved in TE buffer and stored at $-20^{\circ} \mathrm{C}$ until further use.

\section{Agarose gel electrophoresis}

Samples were analyzed using 1.5\% agarose gel electrophoreses in a 1X TBE $(10 \mathrm{mM}$ Tris-base, $\mathrm{pH} 8 ; 2.75 \mathrm{~g} / \mathrm{L}$ boric acid; $1 \mathrm{mM}$ EDTA-HCl, $\mathrm{pH}$ 8) solution and visualized under a UV transilluminator after staining with $0.5 \mu \mathrm{g} / \mathrm{mL}$ ethidium bromide. 


\section{DNA quality assessment}

DNA concentration and purity were assessed using a UV spectrophotometer. DNA purity was determined by calculating the absorbance ratios $\mathrm{A}_{260} / \mathrm{A}_{280}$ and $\mathrm{A}_{260} / \mathrm{A}_{230}$ (Table 1).

\section{PCR amplification}

The PCR amplification was performed using the mtDNA sample for the mitochondrial COXIII gene (NCBI accession No. X52539), nuclear $\beta$-actin gene (NCBI accession No. AB181991), and chloroplast (rbcL) gene (NCBI accession No. HQ894419). The primers used are shown in Table 2. PCRs were performed in $20-\mu \mathrm{L}$ volumes with $50 \mathrm{ng}$ mtDNA, $6 \mu \mathrm{L}$ $\mathrm{ddH}_{2} \mathrm{O}, 1 \mu \mathrm{L}$ (forward and reverse) primer for each specific-gene (COXIII gene, $\beta$-actin, and chloroplast genes), and $10 \mu \mathrm{L}$ master mix (Thermo Scientific, Waltham, MA, USA). Reactions were performed in an Eppendorf Mastercycler (Hamburg, Germany) using the following temperature profile: $94^{\circ} \mathrm{C}$ for $5 \mathrm{~min}$ followed by 5 cycles at $94^{\circ} \mathrm{C}$ for $1 \mathrm{~min}, 60^{\circ} \mathrm{C}$ for $30 \mathrm{~s}$ and $70^{\circ} \mathrm{C}$ for $1 \mathrm{~min}, 35 \mathrm{cycles}$ for $50 \mathrm{~s}$ at $94^{\circ} \mathrm{C}, 1 \mathrm{~min}$ at $60^{\circ} \mathrm{C}$, and $50 \mathrm{~s}$ at $72^{\circ} \mathrm{C}$, and a final extension at $72^{\circ} \mathrm{C}$ for $6 \mathrm{~min}$. PCR products were separated by $1.5 \%(\mathrm{w} / \mathrm{v})$ agarose gel electrophoresis and ethidium bromide staining.

\section{AFLP marker analysis}

The AFLP marker (Fermentas) analysis system was applied by following the standard protocol described by Vos et al. (1995). Informative EcoRI:MseI primer pairs (Table 3) were selected and applied to assay the mtDNA quality in this study.

\section{RESULTS AND DISCUSSION}

In any molecular biology study, DNA quality is more important than its quantity. However, isolation of quality DNA from mitochondria is very difficult because presence of genomic DNA, plastid DNA, RNA, polysaccharides, and other metabolites. Varma et al. (2007) reported that extraction of large amounts of high-value, high molecular weight DNA can be limited by the presence of large amounts of phenolic compounds, DNases, and organelle DNA. Some DNA extraction methods have numerous potential limitiations, including risks of cross-contaminations because of the large number of steps involved, lower molecular mass of extracted DNA because of degradation, and samples that are unsuitable for high-throughput applications because of the longer extraction time required (Tan and Yiap, 2009; Turci et al., 2011; Yang et al., 2011). In this study, 2 modified methods (cited here as Methods I and II) were compared. mtDNA extraction using the sucrose gradient protocol (Tang et al., 2005) gave a low DNA yield, and contamination of plastid DNA, RNA, polysaccharides, and protein was observed by spectrophotometric analysis. Karaca et al. (2005) reported that the polysaccharides, proteins, phenolic compounds, tannins, and pigments interfere with several biological enzymes such as DNA polymerases, ligases, and restriction endonucleases. The samples were viscous, and upon gel electrophoresis 5 type bands were visualized. Moreover, DNA was found to be stacked in the wells and showed protein smearing, confirming the presence of plastid DNA, RNA, polysaccharides, and protein contamination (Table 1 No. 1 and Figure 1). According to Meyer (2003), a higher value of $\mathrm{A}_{260} / \mathrm{A}_{280}$ ratio 
indicates RNA contamination, whereas a lower value indicates protein contamination. The $\mathrm{A}_{260}{ }^{\prime}$ $\mathrm{A}_{280}$ ratio is typically used to determine the purity of isolated DNA. This ratio for pure doublestranded DNA is generally considered to be 1.8-1.9 (Sambrook et al., 1989). We analyzed the sample to determine whether it contained DNA or RNA; $30 \mathrm{~mL}$ mtDNA was added to 2 PCR tubes, and $1 \mathrm{~mL}$ RNase enzyme was added to sample 1 and $1 \mathrm{~mL}$ DNase I enzyme to sample 2. The tubes were incubated at $37^{\circ} \mathrm{C}$ for $60 \mathrm{~min}$. DNase I enzyme removed DNA, while RNase enzyme eradicated only RNA and other impurities (plastid DNA, etc.) in sample 1 (Figure 2). The reproducibility and quality of the DNA results could not be tested using PCR because falsenegative polymorphic bands can appear as a result of contamination by DNA-binding substances such as polysaccharides, deactivation of enzymes such as nucleases, or physical methods that can cause shearing of DNA. The pollutants can weaken the detection of polymorphisms between different individuals (Gelfand and White, 1990; Weising et al., 1995). The mtDNA appeared to be contaminated with plastid DNA, RNA, polysaccharides, and protein. DNase I enzyme and RNase enzyme treatment was used to generate purified wheat mtDNA samples (Tables 1, 2 and Figure 3). These treatments can be adjusted as needed for different plant species until the nuclear DNA amplification is undetectable (Gianniny et al., 2004). We then adjusted the concentrations of DNase I and RNase enzyme to completely remove these impurities. After these modifications, a light smear was still present following electrophoresis and the mean value of $\mathrm{A}_{260} / \mathrm{A}_{280}$ was 2.08 (Tables 1-3 and Figure 4). Intact, fragmented, or partially degraded DNA contains lower amounts of proteins and polysaccharides and are efficiently amplified by PCR; however, degraded DNA is not suitable for long PCR, endonuclease digestion, Southern blot analysis, or DNA library construction studies (Michiels et al., 2003).

Table 1. Spectrophotometer values of mtDNA.
\begin{tabular}{lcccc}
\hline Sr. No. & Dnase I:RNA enzyme $(\mu \mathrm{L})$ & $\mathrm{A}_{260} / \mathrm{A}_{280}$ & $\mathrm{~A}_{260} / \mathrm{A}_{230}$ & $\mathrm{mtDNA}(\mathrm{ng} / \mu \mathrm{L})$ \\
\hline 1. & $8: 1$ & 2.25 & 1.56 & 685 \\
2. & $8: 2$ & 2.10 & 1.69 & 328 \\
3. & $8: 4$ & 2.08 & 1.81 & 573 \\
4. & $10: 8$ & 1.89 & 2.07 & 691 \\
\hline
\end{tabular}

Spectrophotometer values of wheat line 90-110, mitochondrial DNA.

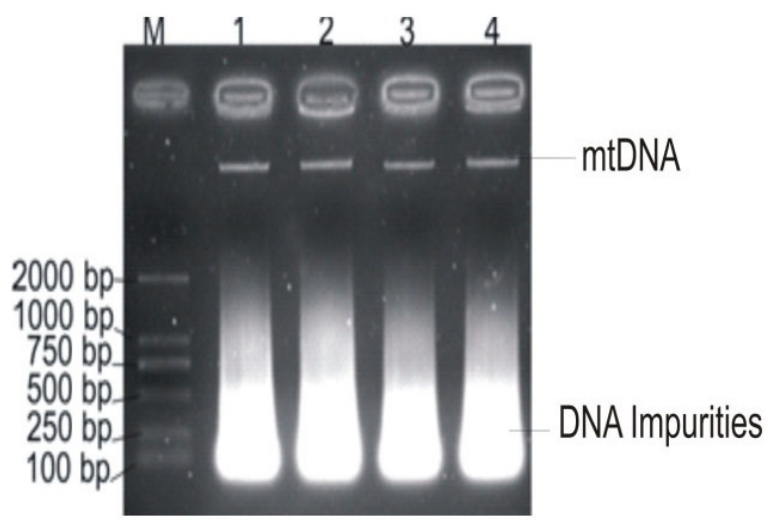

Figure 1. Isolated mtDNA from wheat line 90-110 (method I). Lane $M=$ marker; lanes $1-4=$ mtDNA, fire-like bands indicate RNA, undigested DNA, and other impurities. 


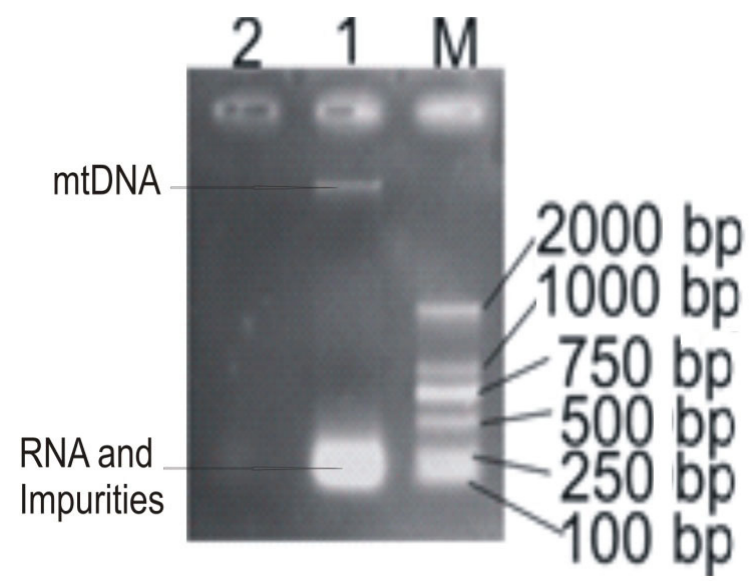

Figure 2. mtDNA isolated from wheat line 90-110 enzyme (DNase I and RNase) treatment. Lane $M=$ marker; lane 1 = RNase enzyme treatment (lower band indicates RNA and other bands indicate impurities); lane 2 = DNase I enzyme treatment (digested the entire DNA).

Table 2. Primer pair (forward and reverse) sequence of mitochondria, nuclear, and chloroplast genes.

\begin{tabular}{lll}
\hline Gene & Nucleotide sequence (5' to 3') & Type of gene \\
\hline COXIII-F & GTATGGTGGCGGGATGTTCT & Mitochondria \\
COXIII-R & TAGTGGAGGGTGCTTGGTAA & Nuclear \\
$\beta$-actin-F & CATAAAGGAGAAGCTCGCTTAC & \\
$\beta$-actin-R & TCTCTTTGCTCATGCGATCAG & Chloroplast \\
rbcL-F & ATTACTTGAATGCGACTGCG & \\
rbcL-R & GCCAAACATGAATACCACCT & \\
\hline
\end{tabular}

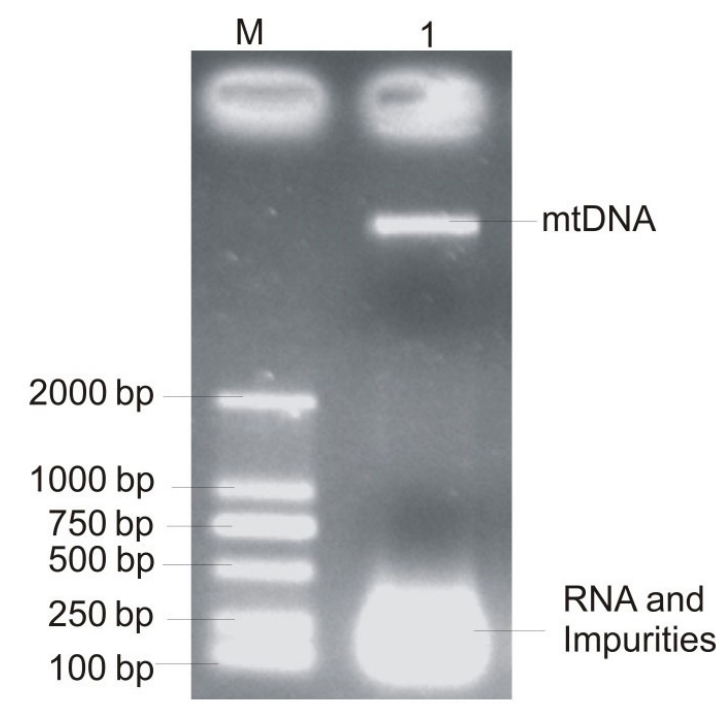

Figure 3. Isolated mtDNA from wheat line 90-110 (Method I). Lane $M=$ marker; lane $1=$ mtDNA, fire-like bands indicate RNA, undigested DNA, and other impurities. 
Table 3. Amplified fragment length polymorphism primer sequences.

\begin{tabular}{ll}
\hline Code & Primer sequence \\
\hline $\mathrm{E}_{4}$ & 5'-GTA GAC TGC GTA CCA ATTC ACT-3' \\
$\mathrm{M}_{2}$ & 5'-GAC GAT GAG TCC TGA GTAA CAC-3' \\
\hline
\end{tabular}

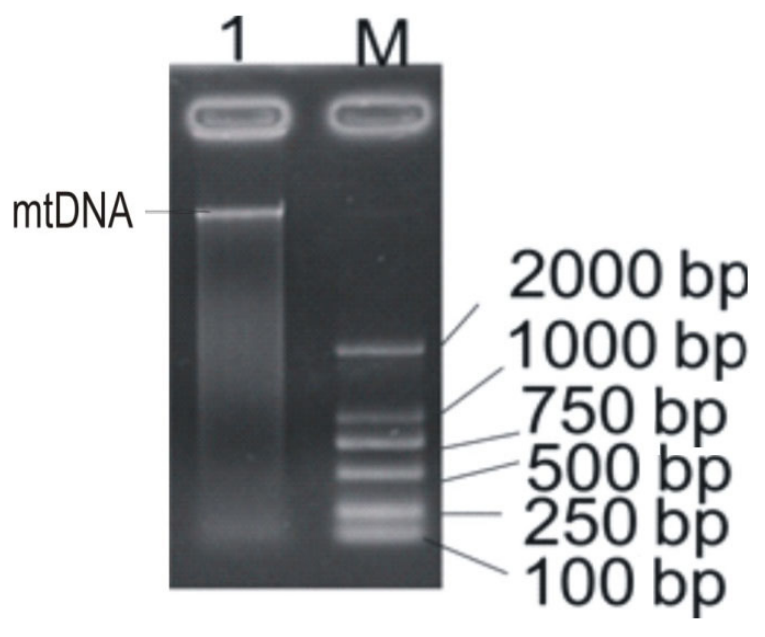

Figure 4. Extracted mtDNA from wheat line 90-110 using Method I. The DNase I:RNase enzyme ratio was 8:4 $\mu \mathrm{L}$. Lane $M=$ marker; lane $1=$ mtDNA; light smear band indicates the impurities present in the mtDNA.

We next examined the efficiency of Method II. Different DNase I:RNase enzyme ratios were tested $(5: 3,8: 5,5: 3$, and 10:5 $\mu \mathrm{L}$ ) to purify the mtDNA (Figure 5). Based on the results of these experiments, we selected $10 \mu \mathrm{L}$ DNase I and $5 \mu \mathrm{L}$ RNase enzyme. To completely eliminate the lower band and smear, as well as to obtain pure mtDNA, we increased the incubation time with the DNase I enzyme $\left(37^{\circ} \mathrm{C}\right)$ from 60 to $90 \mathrm{~min}$. There was no detectable difference between the results for different incubation times (Figure 6). We then maintained a constant DNase I enzyme concentration and changed the RNase enzyme concentration from 5 to $8 \mu \mathrm{L}$. We observed a clear mtDNA band with no smear or lower band (Figure 7), indicating good-quality mtDNA. DNA obtained using this mtDNA extraction method was relatively free of contaminants and was of sufficiently high-quality for other downstream processes. Ince et al. (2009) and Turci et al. (2011) reported that good DNA extraction methods should yield adequate, intact, and pure DNA in a short period of time at low cost and should be suitable for a large number of plant species.

To evaluate mtDNA purity, we investigated samples by amplifying the mitochondrial COXIII, nuclear $\beta$-actin gene, and $\mathrm{rbcL}$ genes (Table 2). The products were separated by $1.5 \%(\mathrm{w} / \mathrm{v})$ agarose gel electrophoresis. The $400-\mathrm{bp}$ mitochondrial COXIII gene was amplified, while the $\beta$-actin and $\mathrm{rbcL}$ genes were not amplified, and thus the mtDNA was not contaminated (Figure 8). The spectrophotometer mean values at $\mathrm{A}_{260} / \mathrm{A}_{280}$ and $\mathrm{A}_{260} / \mathrm{A}_{230}$ ratios using this method were 1.89 and 2.07, respectively (Tables 1-4). These values indicate goodquality mtDNA. According to Clark (1997), DNA purity can be determined by calculating the absorbance ratio of $\mathrm{A}_{260} / \mathrm{A}_{280}$. Pure DNA has a ratio of $1.8 \pm 0.2$. 


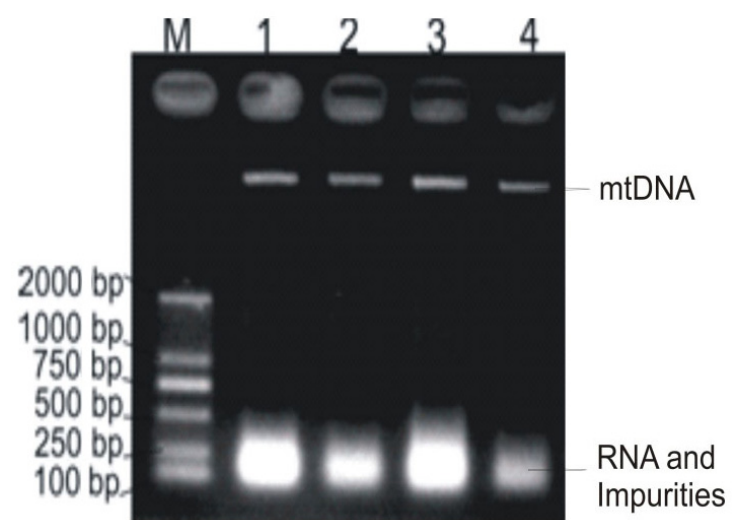

Figure 5. Extracted mtDNA from wheat line 90-110 using different enzyme treatments (Method II). Lane $M=$ marker (DNase I:RNase enzyme ratio); lane $1=5: 3 \mu \mathrm{L}$; lane $2=8: 5 \mu \mathrm{L}$; lane $3=5: 3 \mu \mathrm{L}$; lane $4=10: 5 \mu \mathrm{L}$. Impurities are present in all DNase I and RNase enzyme treatments, but there was less in the 4th treatment.

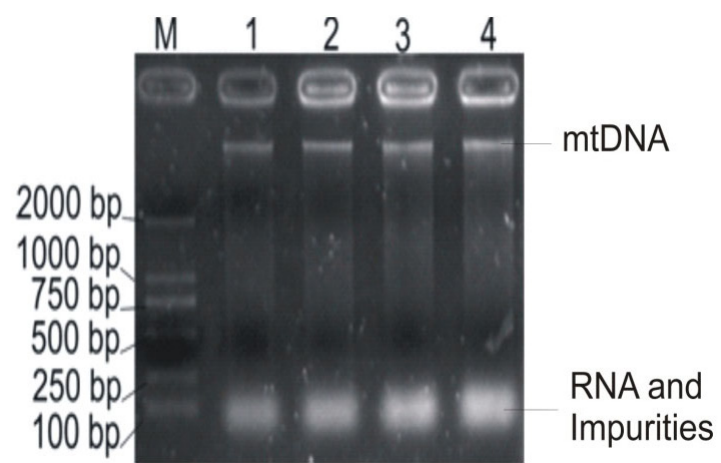

Figure 6. Isolated mtDNA from wheat line 90-110 using different incubation times (Method II). Lane $M=$ marker, lanes 1 and $2=90 \mathrm{~min}$; lanes 3 and $4=60 \mathrm{~min}$. Increasing the time to $90 \mathrm{~min}$ did not completely remove the RNA and impurities.

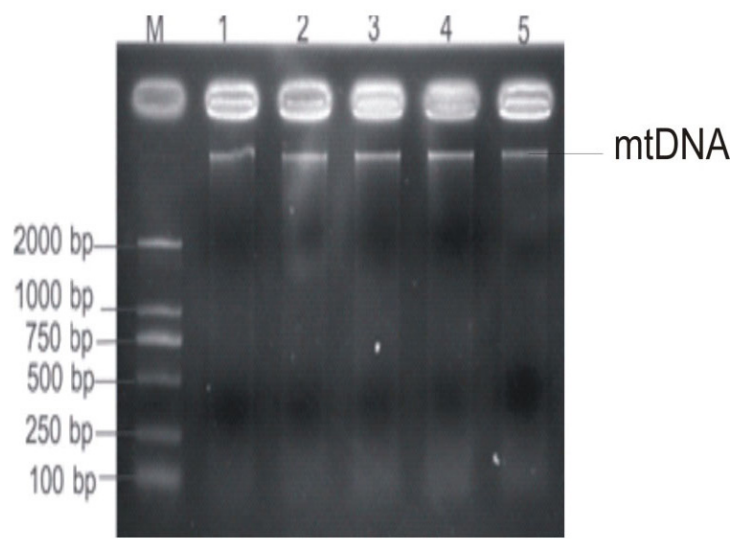

Figure 7. Isolated mtDNA from wheat line 90-110, using Method II. Lane $M=$ marker; lanes $1-5=$ mtDNA. Increasing the DNase I and RNase enzyme ratio to $10: 8 \mu \mathrm{L}$ completely removed the impurities. 


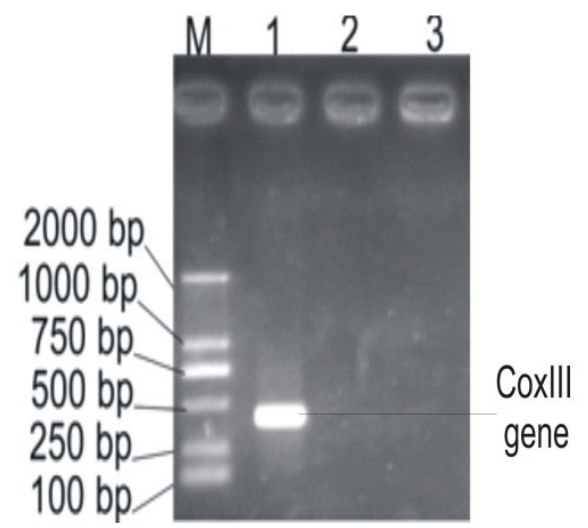

Figure 8. Purity test of mtDNA extracted from wheat line 90-110. Lane $M=$ marker; lane $1=$ COXIII gene; lane $2=\beta$-actin; lane $3=$ chloroplast $(\mathrm{rbcL})$ gene. COXIII gene amplified about $400 \mathrm{bp}$, while the other 2 genes were not amplified.

Further, we investigated mtDNA quality by restriction with an AFLP marker. The edifying primer pair $\mathrm{E}_{4} / \mathrm{M}_{2}$ (Table 3 ) was used in this study, which produced 5 good-quality bands. The highest band produced by this primer was $400 \mathrm{bp}$, confirming the presence of pure mtDNA (Figure 9). The reproducibility of PCR-based molecular marker methods depends on the quality of the template DNA (Yamada et al., 2002).

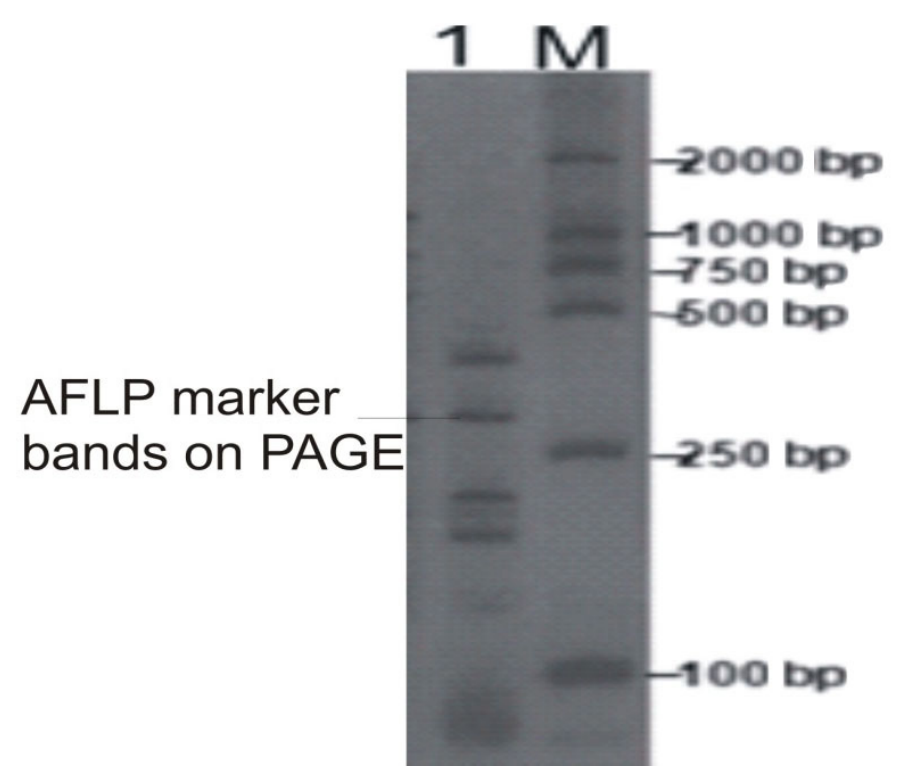

Figure 9. AFLP marker amplification profiles of wheat line 90-110. Lane $M=$ marker; lane $1=$ primer $\mathrm{E}_{4} / \mathrm{M}_{2}$, which produced 5 clear bands on PAGE. 


\section{CONCLUSIONS}

In this study, we determine the most effective method for extracting mtDNA. Two critical factors taken into account when comparing mtDNA extraction protocols were DNA yield and quality (Csaikl et al., 1998). Based on the gel electrophoreses, UV spectrophotometer analyses, PCR amplification analyses, and AFLP marker restriction results, Method II was superior for the extraction of mtDNA from wheat (T. aestivum) yellow etiolated shoots. mtDNA yield was $691 \mathrm{ng} / \mu \mathrm{L}$ and quality based on the $\mathrm{A}_{260} / \mathrm{A}_{280}$ ratios was 1.89 (Table 1). In addition, using the AFLP marker primer pair $\mathrm{E}_{4} / \mathrm{M}_{2}$ (Table 3), the highest band of 400 bp were amplified from the sample (extracted mtDNA from Method II). These results indicated that the quality and quantity of mtDNA were sufficiently good for PCR amplification and other downstream processes. Obtaining good-quality DNA is essential for subsequent experiments, particularly those involving PCR, in which excess of cell debris and proteins can inhibit the amplification process (Mullis et al., 1992). Hence, the findings in this study can be used as a guide for selecting an appropriate method to extract quality and quantity mtDNA from a specific crop.

\section{ACKNOWLEDGMENTS}

Research supported by the National High Technology Research and Development Program of China (\#2011AA10A106), the National Natural Science Foundation of China (\#31371697, \#31171611), and the Key Scientific and Technological Innovation Special Projects of Shaanxi Province "13115” (\#2014KTZB02-01-02).

\section{REFERENCES}

Adsule RN and Kadam SS (1986). Quality of Wheat and Wheat Products. Metropolitan Book Co., New Delhi, 1-6.

Clark MS (1997). Plant Molecular Biology - A Laboratory Manual. Springer-Verlag, Berlin, Hiedelberg, New York, 305328.

Csaikl UM, Bastian H, Brettschneider R, Gauch S, et al. (1998). Comparative analysis of different extraction protocols: A fast, universal maxi-plant-preparation of high quality plant DNA for genetic evaluation and phylogenetic studies. Plant Mol. Biol. Rep. 16: 69-86.

Gelfand DH and White TJ (1990). Thermo Stable DNA Polymerases. In: PCR Protocols: A Guide to Methods and Applications (MA Innis and DH, eds.). Academic Press, San Diego, 129-141.

Gianniny C, Stoeva P, Cheely and Dimaculangan D (2004). RAPD analysis of mtDNA from tomato flowers free of nuclear DNA artifacts. Biotechniques 36: 772-774, 776.

Harlan JR (1981). The Early History of Wheat. Wheat Science Today and Tomorrow. Cambridge University Press, Cambridge, 1-9.

Ince AG, Karaca M and Onus AN (2009). Development and utilization of diagnostic DAMD-PCR markers for Capsicum accessions. Genet. Resour. Crop Evol. 56: 211-221.

Karaca M, Ince AG, Elmasulu SY, Onus AN, et al. (2005). Co-isolation of genomic and organelle DNAs from 15 genera and 31 species of plants. Anal. Biochem. 343: 353-355.

Li WQ, Zhang GS, Wang K, Niu N, et al. (2007). An efficient method for isolation of mitochondrial DNA in wheat. $Y i$ Chuan 29: 771-775.

Lynch M, Koskella B and Schaack S (2006). Mutation pressure and the evolution of organelle genomic architecture. Science 311: 1727-1730.

Meyer R (2003). Detection Methods for Genetically Modified Crops. In: Genetically Engineered Food: Methods and Detection. Wiley-VCH GmbH and Co., KGaA, Weinheim, 188-200.

Michiels A, Van den Ende W, Tucker M, Van Riet L, and et al. (2003). Extraction of high-quality genomic DNA from latex-containing plants. Anal. Biochem. 315: 85-89. 
Mullis K, Faloona F, Scharf S, Saiki R, et al. (1992). Specific enzymatic amplification of DNA in vitro: the polymerase chain reaction. Biotechnology 24: 17-27.

Puchooa D (2004). A simple, rapid and efficient method for the extraction of genomic DNA from lychee (Litchi chinensis Sonn.). Afr. J. Biotechnol. 3: 253-255.

Sambrook J, Fritsch EF and Maniatis T (1989). Molecular Cloning: A Laboratory Manual. Cold Spring Harbor Laboratory Press, Cold Spring Harbor.

Schnable PS and Wise RP (1998). The molecular basis of cytoplasmic male sterility and fertility restoration. Trends Plant Sci. 3: 175-180.

Schuster W and Brennicke A (1994). The plant mitochondrial genome: physical structure, information content, RNA editing, and gene migration to the nucleus. Annu. Rev. Plant Physiol. Plant Mol. Biol. 45: 61-78.

Tan SC and Yiap BC (2009). DNA, RNA, and protein extraction: the past and the present. J. Biomed. Biotechnol. 2009: 574398.

Tang Q, Yao YQ, Zhang GS, Niu N, et al. (2005). Establishment of the simple extraction method of wheat mitochondrial DNA. J. Triticeae Crops 25: 144-147.

Turci M, Sardaro MLS, Visioli G, Maestri E, et al. (2011). Evaluation of DNA extraction procedures for traceability of various tomato products. Food Control 21: 143-149.

Varma A, Padh H and Shrivastava N (2007). Plant genomic DNA isolation: an art or a science. Biotechnol. J. 2: 386-392.

Vos P, Hogers R, Blecker M, Reijans M, et al. (1995). AFLP: a new technique for DNA fingerprinting. Nucleic Acids Res. 23: 4407-4414.

Weising K, Nybom H, Wolff K and Meyer W (1995). DNA Fingerprinting in Plants and Fungi. CRC Press, Boca Raton.

Wilkie SE, Issac PG and Slater RJ (1993). Random amplification polymorphic DNA (RAPD) markers for genetic analysis in Allium. Theor. Appl. Genet. 86: 497-504.

Yamada Y, Makimura K, Merhendi H, Ueda K, et al. (2002). Comparison of different methods for extraction of mitochondrial DNA from human pathogenic yeasts. Jpn. J. Infect. Dis. 55: 122-125.

Yang GY, Erdman DE, Kodani M, Kools J, et al. (2011). Comparison of commercial systems for extraction of nucleic acids from DNA/RNA respiratory pathogens. J. Virol. Methods 171: 195-199. 